\title{
PENINGKATAN PRESTASI KERJA MELALUI PENGEMBANGAN KARIR
}

\author{
Ipong Dekawati \\ Program Pascasarjana Universitas Wiralodra Indramayu \\ ipongdekawati@unwir.ac.id
}

\begin{abstract}
ABSTRAK
Pada era sekarang guru sebagai pendidik, tidak cukup dengan dapat menjalankan tugasnya melaksanakan pembelajaran. Tetapi dalam proses pelaksanaan tugas pembelajaran tersebut juga harus berprestasi jika tidak ingin kalah bersaing dalam berkarir. Peningkatan prestasi kerja guru dalam melaksanakan pembelajaran merupakan suatu keniscayaan. Sangat kuat dugaan pengembangan karir merupakan faktor dominan yang mendorong peningkatan prestasi kerja. Fokus penelitian ini adalah untuk mengetahui pengaruh pengembangan karir terhadap prestasi kerja guru. Pendekatan penelitian merupakan campuran kulaitatif dan kuantitatif. Teknik pengumpulan data menggunakan angket skala Likert, terhadap 72 orang guru. Pengolahan hasil penelitian menggunakan teknik analisis regresi. Uji signifikansi menggunakan uji-F. Setelah melaksanakan dan membahas hasil penelitian ini, penulis dapat menyimpulkan bahwa pengembangan karir berpengaruh positif dan signifikan terhadap prestasi kerja guru. Maknanya, peningkatan prestasi kerja guru dapat dilakukan melalui pengembangan karir guru. Kondisi manajemen pengembangan karir juga masih terdapat kelemahan terutama pada sisi kesetiaan terhadap institusi, jaringan dan prestasi kerja guru. Maka disarankan agar ditingkatkan kesempatan bagi guru untuk berkonsultasi dan mengerjakan pekerjaan dengan kemampuan terbaiknya. Keterbukaan dalam pengukuran dan sistem kinerja, transparan dalam penilaian prestasi kerja serta membantu guru untuk melebarkan jaringan kerjanya dalam melaksanakan pengembangan karir.
\end{abstract}

Kata Kunci: Pengembangan Karir, Prestasi Kerja. 


\title{
IMPROVING TEACHER'S JOB PERFORMANCE THROUGH DEVELOPMENT OF TEACHER CAREER
}

\author{
Ipong Dekawati \\ Postgraduate Program at Wiralodra University Indramayu \\ ipongdekawati@unwir.ac.id
}

\begin{abstract}
In the current era of teachers as educators, it is not enough to be able to carry out their duties carrying out learning. But in the process of implementing these learning tasks must also excel if they do not want to compete in a career. Improving teacher work performance in carrying out learning is a necessity. There is a strong suspicion that career development is the dominant factor that drive work performance improvement. The focus of this study is to investigate the effect of career development on teacher work performance. The research approach is a mixture of quantitative and qualitative. Data collection techniques using a Likert scale questionnaire, of 72 teachers. Processing of research results using regression analysis techniques. The significance test uses the F-test. After carrying out and discussing the results of this study, the author can conclude that teacher career development has a positive and significant effect on teacher work performance. There are still several weaknesses in the management of career development, especially in terms of loyalty to institutions, networks and teacher work performance. So it is suggested that the opportunity for teachers to be consulted and do the work to the best of their ability be increased. Openness in measurement and performance systems, transparent in evaluating work performance and helping teachers to widen their networks in carrying out career development.
\end{abstract}

Keywords: Career Development, Job Performance. 


\section{A. PENDAHULUAN}

Pendidikan merupakan salah satu unsur penting dalam membentuk manusia yang berbudi luhur, berkarakter dan memiliki pengetahuan yang memadai. Hal ini berlangsung dari sebelum bahkan setelah berlangsungnya pentahapan, era industri

dari 1.0 hingga sekarang sudah sampai pada tahap 4.0. Pendidikan memiliki peran yang signifikan dalam mencapai kemajuan ilmu pengetahuan dalam mengimbangi era 4.0 tersebut. Bagaimanapun pendidikan merupakan lokomotif kemajuan di berbagai bidang kehidupan: sosial, ekonomi, politik, dan budaya. Dalam pencapaian tersebut, Pemerintah memiliki kewajiban untuk meningkatkan kualitas hidup manusia melalui pembangunan pendidikan itu sendiri. Sebagaimana diamanatkan oleh UUD 1945, yang mewajibkan Pemerintah bertanggung jawab dalam mencerdaskan kehidupan bangsa dan mewujudkan kesejahteraan umum.

Upaya pemerintah dalam meningkatkan kualitas hidup manusia melalui pendidikan terus dilakukan dengan memberikan pelayanan publik di bidang pendidikan yang maksimal kepada masyarakat. Kenyataan menunjukkan, dari delapan standar pelayanan yang ada baik kuantitas maupun kualitasnya. Petugas paling depan dan selalu dianggap masyarakat merupakan yang paling bertanggung jawab dalam mutu pelayanan pendidikan adalah guru. Oleh karenanya, guru harus berprestasi, agar mampu mengimbangi dinamika yang diinginkan oleh pengguna institusi pendidikan.

Pelaksanaan pelayanan publik dalam bidang pendidikan yang dilakukan agar dapat berjalan secara optimal dan bermutu, tentunya perlu dilakukan pengembangan karir terhadap guru itu sendiri. Tujuan dari seluruh program pengembangan karir adalah untuk menyesuaikan antara kebutuhan dan tujuan guru dengan kesempatan karir yang tersedia pada institusi saat ini dan di masa mendatang. Karena itu, usaha pembentukan sistem pengembangan karir yang dirancang secara baik akan dapat membantu guru dalam menentukan kebutuhan karir mereka sendiri, dan menyesuaikan antara kebutuhan guru dengan tujuan pendidikan/sekolah.

\section{B. PENGEMBANGAN KARIR DAN PRESTASI KERJA}

Pengembangan karir

diharapkan oleh setiap guru/pegawai di sekolah, karena dengan pengembangan karir ini akan mendapatkan hak-hak yang lebih baik dari apa yang diperoleh sebelumnya baik material maupun non material misalnya, kenaikan, pendapatan, perbaikan fasilitas, dan sebagainya. Sedangkan hak-hak yang tidak bersifat material misalnya status sosial, perasaan bangga dan sebagainya. Dalam praktek pengembangan karir lebih merupakan suatu pelaksanaan rencana karir seperti yang diungkapkan oleh Handoko (2000:123) bahwa pengembangan karir adalah "peningkatan-peningkatan pribadi yang dilakukan seseorang untuk mencapai suatu rencana karir".

Pengembangan karir adalah "proses peningkatan kemampuan kerja individu yang dicapai dalam rangka mencapai karir yang diinginkan" (Rivai (2004:274)). "Pengembangan karir yaitu setiap karyawan harus mempunyai gambaran yang jelas tentang anak tangga tertinggi apa yang bisa dicapainya selama dia menampilkan kinerja yang memuaskan" (Siagian, 2006:203). Dengan demikian, pengembangan karir merupakan suatu proses dalam peningkatan dan penambahan kemampuan seseorang guru/pegawai yang dilakukan secara formal dan berkelanjutan untuk 
mencapai sasaran dan tujuan karirnya. Betapa pun baiknya suatu rencana karir yang telah dibuat oleh seseorang guru disertai tujuan karir $\mathrm{K}$ yang wajar dan realistik, rencana tersebut tidak akan menjadi kenyataan tanpa adanya pengembangan karir yang sistemik. Meskipun bagian pengelolaan sumber daya manusia dapat turut berperan dalam kegitan pengembangan tersebut, sesungguhnya yang paling bertanggung jawab adalah guru yang bersangkutan sendiri. Hal ini merupakan salah satu prinsip pengembangan karir yang sangat fundamental. Kelancaran pengembangan karir, selain sangat tergantung pada individu guru, juga banyak factor lain yang mempengaruhinya. Sebagaimana disampaikan Siagian (2006:215), bahwa faktor-faktor yang mempengaruhi pengembangan karir seorang pegawai adalah: (1) Prestasi kerja yang memuaskan. Prestasi kerja merupakan pangkal tolak pengembangan karir seseorang, tanpa prestasi kerja yang memuaskan, sulit bagi seorang pekerja untuk diusulkan oleh atasannya untuk dipromosikan. (2) Pengenalan oleh pihak lain. Adalah berbagai pihak yang berwenang memutuskan layak tidaknya seseorang dipromosikan seperti atasan langsung dan pemimpin bagian kepegawaian yang mengetahui kemampuan dan prestasi kerja seorang pegawai. (3) Kesetiaan pada organisasi. Merupakan dedikasi seorang karyawan yang ingin terus berkarya dalam organisai tempatnya bekerja untuk waktu yang lama. (4) Pembimbing dan sponsor. Pembimbing adalah orang yang memberikan nasehat-nasehat atau saran-saran kepada karyawan dalam upaya mengembangkan karirnya.Sedangkan sponsor adalah seorang yang di dalam perusahaan yang dapat menciptakan kesempatan bagi karyawan untuk mengembangkan karirnya. (5) Dukungan para bawahan. Dukungan dari karyawan mensukseskan tugas manajer. Kesempatan untuk bertumbuh. Kesempatan yang diberikan kepada karyawan untuk meningkatkan kemampuannya, baik melalui pelatihanpelatihan, kursus, dan juga melanjutkan jenjang pendidikannya. (7) Pengunduran diri sendiri. Merupakan keputusan dari diri sendiri untuk berhenti bekerja dan beralih ke isntitusi/organisasi lain yang memberikan kesempatan lebih besar untuk mengembangkan karir.

Penilaian pengembangan karir guru dalam penelitian ini menggunakan komponen pengembangan karir milik Siagian (2006), tetapi komponen bawahan yang mempunyai dukungan dari pihak bawahan tidak dipergunakan, karena hubungan antara atasan dan bawahan tidak ada yang ada teman sejawat yaitu sesame guru. Oleh karena itu, aspek pengembangan karir yang digunakan penulis adalah: (1) prestasi kerja, (2) pengenalan oleh pihak lain, (3) kesetiaan terhadap organisasi, (4) pembimbing dan sponsor, (6) kesempatan untuk tumbuh, dan (7) pengunduran diri.

Prestasi kerja merupakan hal yang terpenting yang harus dicapai oleh pegawai baik dalam institusi pendidikan maupun institusi lainnya. Karena prestasi kerja merupakan modal utama dalam meniti jenjang karir berikutnya. Prestasi kerja diartikan sebagai "ungkapan kemampuan yang didasari oleh pengetahuan, sikap, keterampilan dan motivasi dalam menghasilkan sesuatu" (Fattah, 2006:19). Pengertian prestasi kerja menurut Fattah ini dapat diinterpretasikan sebagai kegiatan yang dihasilkan seseorang dengan segenap kemampuannya, pengetahuan, keterampilan serta hal-hal yang bersifat individual untuk menciptakan sebuah kinerja yang diakui oleh orang/atasan. Prestasi kerja 
merupakan "kesuksesan seseorang di dalam melaksanakan suatu pekerjaannya" (Maier, 2000:233). Lebih tegasnya prestasi kerja adalah tercapainya keberhasilan yang diperoleh seseorang dari penampilan kerjanya. Penilaian prestasi kerja merupakan "upaya membandingkan prestasi actual pegawai dengan prestasi kerja yang diharapkan dan ahli lainnya seringkali menentukan standar yang akan dicapai dan aktivitas spesifik yang akan dilaksanakan. Perbedaan karakteristik individual ini membutuhkan penyesuaian terhadap situasi tempat kerja dan organisasinya. Respons individu terhadap penyesuaian ini sangat dibutuhkan. Individu harus berusaha sendiri meresponnya sehingga perbedaan karakteristik individual bukan lagi menjadi sebuah permasalahan yang berarti" (Dessler, 2005:82). Berdasarkan dari beberapa definisi di atas, dapat disimpulkan bahwa, prestasi kerja guru merupakan hasil kerja yang dicapai oleh seorang guru dalam melaksanakan tugas-tugas yang diberikan kepadanya sesuai dengan standar yang ditetapkan oleh sekolah. Prestasi kerja seseorang 'dipengaruhi oleh usaha (effort), kemampuan (ability), dan pengamatan terhadap peran (role perceptions). Usaha, yaitu banyaknya energi yang dikeluarkan seseorang dalam situasi tertentu, kemampuan, yaitu potensi seseorang yang sifatnya relatif stabil, dan pengamatan terhadap peran, adalah kesesuaian antara usaha yang dilakukan seseorang dengan pandangan penilai' (Lawler dalam Munandar, 2003:7). Prestasi kerja seseorang dipengaruhi tiga perangkat variabel yaitu variabel individu, variabel organisasi, dan variabel psikologis. Sewaktu individu masuk dan bergabung dalam organisasi: usia, asal-usul, budaya dan keterampilan yang berbedabeda" (Guibert, 2000:xi). "Faktor yang mempengaruhi prestasi kerja, antara lain, sifat, hakikat tugas, sistem imbalan, filsafat manajemen, dan kebijaksanaan organisasi berkaitan dengan kepegawaian" (Zainun, 2005:60). Faktor sistem imbalan memiliki peranan yang berarti terhadap peningkatan prestasi kerja. Sistem imbalan yang baik dan menunjukkan keterbukaan, dalam arti imbalan yang diterima sesuai dengan hasil usaha yang dilakukan mampu meningkatkan motivasi kerja. Dengan semangat dan motivasi yang tinggi disertai rasa tanggung jawab terhadap pekerjaan hasil kerja yang diperoleh menunjukkan peningkatan. Namun prestasi kerja seseorang tidak selamanya tergantung pada sistem imbalan, tetapi juga ada faktor dari dalam diri individu sendiri yang sangat mempengaruhi kinerja seseorang. Individu yang selalu berorientasi pada kebutuhan atas prestasi akan mencerminkan sikap dan perilakunya untuk bertindak yang terbaik guna mencapai hasil yang lebih baik dari sebelumnya, baik dilihat dari segi kualitas maupun kuantitasnya. (Zainun, 2005:61). Faktor-faktor yang mempengaruhi prestasi kerja Supardi (2014:70), antara lain: (1) Kuantitas kerja. Faktor yang meliputi output/keluaran dan target kerja dalam kuantitas kerja. (2) Pengetahuan. Pengetahuan merupakan kemampuan seorang guru dinilai dari pengetahuan mengenai sesuatu hal yang berhubungan dengan tugas dan prosedur kerja, penggunaan alat kerja maupun kemampuan teknis atas pekerjaannya. (3) Penyesuaian pekerjaan. Penyesuaian pekerjaan merupakan indikator penilaian kerja yang ditinjau dari kemampuan guru dalam melaksanakan tugas di luar pekerjaan maupun adanya tugas baru, kecepatan berpikir dan bertindak dalam bekerja. (4) Hubungan kerja. Hubungan kerja yang penilaiannya berdasarkan sikap guru terhadap atasan serta kemudian menerima 
perubahan dalam bekerja. (5) Inisiatif kerja. Inisiatif kerja dilaksanakan bila guru mempunyai ide dan berani mengemukakan. Inisiatif dapat diketahui melalui kecepatan berfikir $k$ dalam bekerja, disiplin dalam menyelesaikan pekerjaan dan kehatihatian dalam bekerja.

Secara umum tujuan penilaian prestasi kerja adalah "untuk mendapatkan informasi yang akurat perbaikan dengan perilaku dan kinerja bagi setiap anggota organisasi dan biasanya dapat digolongkan ke dalam dua bagian yang penting yaitu: tujuan evaluasi dan pengembangan" (Simamora, 2007:500). "Kegunaan penilaian prestasi kerja adalah sebagai berikut: (1) perbaikan prestasi kerja, (2) penyesuaian kompensasi, (3) keputusan penempatan, (4) kebutuhan latihan, (5) perencanaan dan pengembangan karier, penyimpangan proses staffing, kesalahan desain pekerjaan, kesempatan kerja yang adil, dan (10) tantangan eksternal" (Handoko, 2008:135).

Untuk keberlanjutan karirnya baik guru ataupun pegawai lain, perlu dilakukan penilaian prestasi kerja.

Penilaian prestasi kerja akan dapat terlaksana dengan efektif bila ada panduan pelaksanaannya. Gomes (2006:135) memberi saran yang dapat menjadi panduan dalam melakukan suatu penilaian kinerja. Hal ini dapat dianalogikan untuk penilaian prestasi kerja, di antaranya: (1) Sesuaikan kriteria kinerja dengan situasi-situasi

pekerjaan. (2) Gunakan pendekatan penilaian yang berpartisipatit. (3) Fokuskan penilaian pada perilakuperilaku atau pencapaian tujuan. (4) Fokuskan penilaian pada upaya pemecahan masalah ketimbang pada mencari masalah. (5) Sisihkan permasalahan gaji. (5) Berikan latihan-latihan kepada penilai kinerja. Hasibuan (2013:95), menyampaikan unsur-unsur penilaian prestasi kerja, yaitu meliputi: (1) kesetiaan, kejujuran, (3) kedisiplinan, kreatifitas,

(5) kerjasama, kepemimpinan, (7) kepribadian, prakarsa, (9) kinerja, (10) kecakapan, (11) tanggung jawab". Menurut TV Rao (2002:78), prestasi kerja dinilai dari hal-hal sebagai berikut: (1) Tingkat pencapaian target; (2) Inisiatif; (3) Loyalitas dan kerjasama dalam kelompok; (4) Kepatuhan; (5) Disiplin kerja; (6) Kesadaran akan pengembangan diri dan peningkatan pengetahuan

\section{METODOLOGI PENELITIAN}

Pendekatan

penelitian

merupakan campuran kuantitatif dan kualitatif dengan teknik pengumpulan data menggunakan angket. Angket disebarkan kepada 72 orang guru sebagai responden. Jumlah tersebut merupakan sampel dari populasi sebanyak 248 orang guru. Penentuan jumlah sampel menggunakan rumus Slovin dan teknik pengambilan sampel secara simple random sampling. Angket yang digunakan dalam penelitian ini adalah angket tertutup (angket berstruktur), yaitu angket yang disajikan dalam bentuk sedemikian rupa sehingga responden diminta untuk memilih satu jawaban yang sesuai dengan pengalaman dan penilaiannya dengan cara memberikan tanda checklist $(\sqrt{ })$. Angket yang digunakan dalam penelitian ini adalah dalam bentuk forced choice. Penyebaran angket dilakukan kepada guru Sekolah Menengah Pertama (SMP) Negeri di Kecamatan Jatibarang Kabupaten Indramayu. Indikatorindikator yang merupakan penjabaran dari variabel pengembangan karir guru dan prestasi kerja guru, merupakan materi pokok yang diramu menjadi sejumlah pernyataan dalam angket. Angket yang digunakan dalam penelitian ini adalah angket yang mengacu pada skala Likert sebagai 
bentuk konstruksi item pertanyaan Tabel 2, menunjukkan bahwa: dimensi pada angket menggunakan lima peluang untuk tumbuh berada pada alternatif jawaban dengan kisaran $1-5$. tingkat tertinggi dengan skor $=3,08$ Alternatif jawaban untuk semua (baik), dimensi eksposur pada tingkat variabel adalah: sangat benar (SB), kedua dengan skor $=3,03$ (baik), benar $(B)$, kemudian dimensi kesetiaan terhadap ragu-ragu (RR), tidak benar (TB), dan organisasi dengan skor $=3,01$ (baik), sangat tidak benar (STB). Pengolahan dimensi pembimbing dan sponsor hasil penelitian menggunakan teknik dengan skor $=2,98$ (cukup), dimensi analisis regresi. Uji signifikansi prestasi kerja dengan skor $=2,93$ menggunakan uji-F.

\section{DESKRIPSI HASIL PENELITIAN}

Angket yang terkumpul, diperiksa (cukup), dimensi jaringan kerja dengan skor $=2,92$, dan terakhir dimensi pengunduran diri dengan skor $=2,90$ dan dihitung untuk keperluan perhitungan statistik dan analisis. Dari pengembangan karir guru, telah hasil perhitungan dapat diketahui menunjukkan guru memiliki peluang kondisi masing-masing variabel. untuk berkembang, dan tingkat eksposur Sebagai acuan kriteria kondisi masing- guru dalam berkarir pun berada pada masing variabel digunakan kriteria dari kondisi yang baik. Selain itu, kesetiaan Riduwan (2003:41) sebagai berikut:

Tabel 1: Kriteria Interpretasi Persentase Skor

\begin{tabular}{|c|c|}
\hline $\begin{array}{c}\text { Skor } \\
\text { Persentase }\end{array}$ & $\begin{array}{c}\text { Kriteria } \\
\text { Intrprestasi }\end{array}$ \\
\hline $0 \%-19,99 \%$ & Sangat Buruk \\
\hline $20 \%-39,99 \%$ & Kurang \\
\hline $40 \%-59,99 \%$ & Cukup \\
\hline $60 \%-79,99 \%$ & Baik \\
\hline $80 \%-100 \%$ & Sangat Baik \\
\hline
\end{tabular}
terhadap organisasi (instansi) ditunjukkan guru dengan baik. Kemudian kondisi pembimbing dan sponsor, prestasi kerja, serta jaringan kerja yang terjalinpun dirasakan guru sudah cukup baik. Selain itu, tingkat penurunan pengunduran diri gurupun berada pada kondisi cukup baik.

Menurut TV Rao (2002:78), prestasi kerja dinilai dari hal-hal sebagai berikut:

Beberapa hal yang berkaitan dengan pengembangan karir seseorang karyawan menurut Rivai (2009:295) adalah: prestasi kerja, eksposur, jaringan kerja, pengunduran organisasi, dan peluang untuk tumbuh. (1) Tingkat pencapaian target; (2) Inisiatif; (3) Loyalitas dan kerjasama dalam kelompok; (4) Kepatuhan; (5) Disiplin kerja; (6) Kesadaran akan pengembangan diri dan peningkatan pengetahuan.

Ketujuh komponen tersebut merupakan dimensi pengembangan karir dalam penelitian ini.

Tabel 2: Kondisi Pengembangan Karir Guru

\begin{tabular}{|c|l|c|c|c|c|}
\hline No & Dimensi & $\begin{array}{c}\text { Skor } \\
\text { Capaian }\end{array}$ & $\begin{array}{c}\text { Skor } \\
\text { Maksimal }\end{array}$ & $\begin{array}{c}\text { Persen } \\
\text { tase }\end{array}$ & Kateqori \\
\hline 1 & Prestasi kerja & 2,93 & 5 & $58,60 \%$ & Cukup \\
\hline 2 & Eksposu & 3,03 & 5 & $60,60 \%$ & Baik \\
\hline 3 & Jaringan & 2,92 & 5 & $58,40 \%$ & Cukup \\
\hline 4 & Pengunduran diri & 2,90 & 5 & $58,00 \%$ & Cukup \\
\hline 5 & Kesetiaan terhadap organisasi & 3,01 & 5 & $60,20 \%$ & Baik \\
\hline 6 & Pembimbing dan sponsor & 2,98 & 5 & $59,60 \%$ & Cukup \\
\hline 7 & Peluang untuk tumbuh & 3,08 & 5 & $61,60 \%$ & Baik \\
\hline
\end{tabular}


dimiliki guru akan mempermudah guru dalam kegiatan proses pembelajaran di madrasah". Sebagai bahan perbandingan hasil penelitian Didit Darmawan (2014) yang menyatakan bahwa, "para pimpinan harus secara bijak memperhatikan kebutuhan para guru secara tepat. Semangat kerja guru juga dapat menurun apabila pihak atasan tidak memperhatikan kepentingan para bawahan. Hal ini akan menurunkan semangat kerja para guru".

\section{E. KESIMPULAN DAN SARAN}

Setelah melaksanakan dan membahas hasil penelitian ini, penulis dapat menyimpulkan bahwa pengembangan karir guru berpengaruh positif dan signifikan terhadap prestasi kerja guru, yaitu 29,4\%. Kondisi manajemen pengembangan karir juga masih terdapat kelemahan terutama pada sisi kesetiaan terhadap institusi, jaringan dan prestasi kerja. Maka disarankan agar ditingkatkan kesempatan bagi guru untuk berkonsultasi dan mengerjakan pekerjaan dengan kemampuan terbaiknya. Keterbukaan dalam pengukuran dan sistem kinerja, transparan dalam penilaian kinerja serta membantu guru untuk melebarkan jaringan kerjanya dalam melaksanakan pengembangan karirnya.

\section{DAFTAR PUSTAKA}

Dessler, Gary (2005) Manajemen Sumber Daya Manusia (diterjemahkan oleh Eli Tanya) Edisi Kesembilan, Jakarta: Index Gramedia.

Didit Darmawan, (2014), Pengaruh Kompetensi dan Semangat Kerja terhadap Prestasi Kerja Guru, Jurnal IImiah Manajemen Pendidikan Indonesia Volume I, No. 1, Hal 1 - 14, September 2014.
Fattah, Nanang. (2006). Landasan Manajemen Pendidikan. Bandung: PT. Remaja Rosda Karya.

Gomes, Faustino Cardoso. (2006). Manajemen Sumber Daya Manusia. Yogyakarta: Penerbit Andi.

Guibert, J.J., (2000), Educational Handbook for Helath Personal, New York: WHO.

Handoko, T. Hani. (2008). Dasar-Dasar Manajemen Produksi dan Operasi. Yogyakarta. BPFE.

Handoko T. Hani. (2000). Manajemen Personalia dan Sumberdaya Manusia, Edisi II, Cetakan Keempat Belas. Yogyakarta: BPFE.

Hasibuan, Malayu SP. (2013). Manajemen Sumber Daya Manusia. Jakarta: Bumi Aksara.

Maier, N.R.F., (2000). Manajemen Kepegawaian. Cetakan ke lima. Bandung: Alumni.

Munandar, Aris. (2003). Manajemen

Berbasis Sekolah Antara

Harapan dan Kenyataan, Jakarta: HSAPI dan UNJ.

Rao, T.V., (2002), Penilaian Prestasi Kerja Teori dan Praktek, Jakarta: Pustaka Binaman Pressindo.

Riduwan. (2003). Metode dan Teknik Menyusun Tesis. Bandung:Alfabeta. Rivai.Veithzal (2004). Manajemen Sumber Daya Manusia untuk Perusahaan, Jakarta: Raja Grafindo Persada.

Rivai, Veithzal, dkk. (2009) Performance Appraisal, Jakarta: PT. RajaGrafindo Persada 
Didaktik : Jurnal Pendidikan, ISSN : 2477-5673, E-ISSN : 2614-722X Sekolah

Rusydiati, (2017), Kepuasan Kerja

Guru Terhadap Prestasi Kerja

Guru Dalam Meningkatkan Mutu

Pendidikan di Madrasah,

STUDIA DIDAKTIKA: Jurnal
Ilmiah Bidang Pendidikan, Vol. 11, No. 1, 2017; ISSN 1978-8169, Hal 45-54, Juni 2017.

Siagian. Sondang. P. (2006). Manajemen SDM. Jakarta: Bumi Aksara.

Simamora, Henry. (2007). Manajemen Sumber Daya Manusia Edisi Ketiga.Yogyakarta: STIE YKPN.

Supardi. (2014). Kinerja Guru. Jakarta: Raja Grafindo Persada.

Zainun. Buchari, (2005), Manajemen dan Motivasi, Jakarta: Balai Aksara. 